\title{
ESSAY \\ Enological Frontier of the Southern Cone of America: Cabernet- Sauvignon in Chile and Malbec in Argentina
}

\author{
Pablo Lacoste, and Philippo Pszczolkowski \\ 'University of Santiago, Institute of Advanced Studies. Román Diaz 89, Providencia, Santiago, Chile. \\ ${ }^{2}$ Universidad Mayor, School of Agronomy. Santiago, Chile.
}

\begin{abstract}
P. Lacoste1, and P. Pszczolkowski. 2019. Enological Frontier of the Southern Cone of America: Cabernet-Sauvignon in Chile and Malbec in Argentina. Cien. Inv. Agr. 46(3): 220-233. The article examines the causes of the enological frontier of the Southern Cone of America, located in the Andes Mountains, with the predominance of the Malbec variety to the east of the Andes (Argentina) and of Cabernet-Sauvignon to the west (Chile). It was discovered that this wine boundary was established in the $19^{\text {th }}$ century, when Cabernet-Sauvignon exceeded Malbec with a ratio of nine to one in Chile, while in Argentina, Malbec represented $75 \%$ of the national viticulture. The cause of this divergence is found in the different vinicultural subjects who led the process of expanding and consolidating the French paradigm in each country. In Chile, this role fitted the national bourgeoisie, who were used the capital accumulated in mining, finance and other activities to further the viticulture in their country. The bourgeoisie could abide by a technical mandate that preached the enological superiority of CabernetSauvignon. In contrast, in Argentina, the architects of the expansion were the poor peasants who became small winegrowers. The shortage of capital led them to find a more productive variety, and their conviction led them to persist in the cultivation of Malbec. The rebellion of small winegrowers against the mandate of technocrats laid the foundation for the emergence of Malbec as an emblematic grapevine of Argentina.
\end{abstract}

Keywords: Cabernet-Sauvignon, emblematic grape variety, french paradigm, Malbec, new world viticulture.

\section{Introduction}

The Andes Mountains mark the enological border of the Southern Cone of America, with the Malbec variety to the East (Argentina) and Cabernet-Sauvignon to the West (Chile). The Argentinean vineyards grow 41,000 hectares

Received Mar 08, 2018. Accepted Jun 18, 2019. Corresponding author: pablo.lacoste@usach.cl of Malbec (2017). This is the emblematic grape vineyard of the country and the basis of Argentinean wine exports. Meanwhile, in Chile, the main grape vineyards are Cabernet-Sauvignon, which engage 42,500 hectares of vineyards (2016), and upon whose base the most prestigious wines of economic value and export volume are made. This variety is less valued in Argentina, where only 15,000 hectares are cultivated. In Chile, the Malbec vine has a smaller relevance, with hardly 
2,300 hectares. The remarkable asymmetry between Argentina and Chile, in the sense of the different varietal specialization from each one, represents a paradox and formulates a natural question of investigation. Why has each country specialized in a different stock?

\section{Entrance and propagation of the French grave in the Southern Cone (1840-1910)}

The Malbec and Cabernet-Sauvignon varieties reached the Southern Cone of America in the mid-1 $19^{\text {th }}$ century, within a greater group, formed by the so-called "French grapes" (Del Pozo, 2014; Williot, 2016). Winemakers, technicians and winegrowers in the region lacked the capacity to distinguish between the different French varieties. Accustomed to Spanish Creole varieties with great berries and a loose cluster, the French varieties all seemed equal, with their small berries and compact cluster. For that reason, the specialized literature of the time referred to all the new varieties with the generic name of "French grape" (Del Pozo, 2014; Pszczólkowski, 2016; Pszczólkowski et al., 2018; Aliquo et al., 2017; Molina, 2018).

Within the general process of the introduction of the French grapes in the Southern Cone, Cabernet-Sauvignon and Malbec arrived in Chile and Argentina in the decades of 1840 and 1850, respectively. The early political-institutional organization achieved by Chile through the Constitution of 1833 and the political leadership of Diego Portales facilitated the process of modernization and integration with the world economy. Argentina recently reached this turning point with the Constitution of 1853 and the return of the intellectuals to the country after the civil wars.

The spread of the Cabernet-Sauvignon, Malbec and French grapes was strongly promoted by the state through agricultural or normal farms. The elites in Argentina and Chile were registered within the modernization paradigm so that had their commercial references in England and wine- making in France. Supporters of free trade, open markets and the imitation of the great powers, politicians, economists and businessmen from the Southern Cone agreed on a shared vision of the means that should be put in place to promote the progress and prosperity of their nations. The goal at that time was to attract capital, technology, immigrants and Northern European plants to ensure development (Mateu and Stein, 2008; Del Pozo, 2014; Lacoste, 2019).

At the level of the wine industry, this trend resulted in two essential factors: introducing plants of French grapes, hiring French enologists and agronomists or those who had trained in France, disseminating French knowledge through educational establishments, and promoting the incorporation of French machinery into the cellars, including oak casks of Nancy, machines for grinding grapes, pumps, filters, distillers, etc. At the institutional level, the Quinta Normal in Santiago de Chile (1841) and the Quinta Agronómica in Mendoza (1853), directed by Michel Aimé Pouget, played a decisive role in the promotion and dissemination of the benefits of the French grapes for improving the wine industry in both countries (Mateu y Stein, 2008; Pszczolkowski, 2018). Both settlements were inspired by the School of Paris and accounted for the advancement of the French paradigm in the Southern Cone of America.

Within the overall process of the introduction of French grapes, the varieties of Malbec and Cabernet-Sauvignon were included, both in Chile and in Argentina. In Chile, the French varieties spread from Quinta Normal towards private vineyards in a slow and sustained process. The favored variety was Cabernet-Sauvignon, followed by others such as Pinot Noir, Merlot, Semillon, Petit Verdot, Malbec, among others (Briones, 1995, Del Pozo, 2014; Pszczolkowski, 2018). In Argentina, the process also began with those varieties (Mateu and Stein, 2008; Rodríguez Vázquez, 2010; Barrio, 2010a; 2010b; Lacoste, 2019). The reference was provided by a referent of the matter, Mario Bernard, who had direct contact 
with Michel Pouget: "In the French vineyard I knew the varieties of Pinot Noir, Cabernet and Malbec" (Lucero, 1991).

The installation of the French paradigm in Chile and Argentina was concretized during the second half of the $19^{\text {th }}$ century. At the beginning of the following century, the transformation was visible. In 1908, Chilean vineyards covered 55,125 hectares, including 46,622 with traditional SpanishCreole $(84.5 \%)$ and 8,502 with French grape vines (15.4\%) (Marambio, 1908). In Argentina, the records of the Province of Mendoza for 1912 indicated that this number was 57,764 hectares, including 50,207 for French grape vines (87\%) and 7.557 for creole grape vines (12\%). Obviously, the process was faster in Argentina; however, in both countries, this dynamic was clearly underway and continued to advance throughout the $20^{\text {th }}$ century (Del Pozo, 2014).

\section{The winemakers when facing Malbec and Cabernet-Sauvignon: first reactions}

The propagation of the French varieties in the Southern Cone called upon the technical work of winemakers and agronomists. In the last third of the $19^{\text {th }}$ century, this work was dedicated to identifying the plants that propagated in the vines of Chile and Argentina and elaborating their technical information and recommendations. This included critical definitions of both varieties, Malbec and Cabernet-Sauvignon. The general trend, in both countries, was prioritizing the enological quality of Cabernet-Sauvignon and severely criticizing Malbec.

The ideological position of pro-Cabernet-Sauvignon was consistent with the French paradigm, within which the technicians and winemakers had been formed. In the $19^{\text {th }}$ century, Cabernet-Sauvignon appeared as the star variety of Bordeaux wines, which were experiencing a worldwide boom at that time. However, Malbec came from Cahors, a wine-growing region located in the center- south of France, near Toulouse. Its apogee in the Middle Ages, when the city occupied a central place economically, culturally and socially, as well as the presence of a university (the second in France) and the prestige of having one of the city's former residents serving as Pope (Juan XXII) contributed to strengthening the prestige of Cahors and its wines. The "black wine of Cahors" was celebrated by kings, popes, nobles and even by Dante Aligheri in the Divine Comedy. During the $18^{\text {th }}$ century, this wine became stronger (Figeac, 2016). Particularly interesting is the history of Malbec in Russia (Nérand, 2016). After suffering decline in the $19^{\text {th }}$ century because of philoxere, Malbec was revived in the 20th and $21^{\text {st }}$ centuries (Griset and Laborie, 2016).

A negative mantle covered the Malbec variety in those times of enological science configuration with the definition of names and ampelography ( $19^{\text {th }}$ century). The denomination of this vineyard already had a negative connotation in France, where the name "would have resulted in the expression mal bec, which means 'bad peak', alluding to the astringency which was present the wines of this variety" (Pszczólkowski, 2016).

The negative view of the Malbec vineyard, prevailing in France in the $19^{\text {th }}$ century, spread through emblematic academic spaces, such as Montpellier and Conegliano. Many technocrats of the Southern Cone of those years had formed in those training centers, including Rene Lefeuvre, Luis Noussan and Aaron Pavlovsky in Montpellier and Leopoldo Suárez in Conegliano; other local influential technicians affirmed their knowledge of wine in specially planned trips to visit warehouses and French vineyards, as was the case of Manuel Rojas (Briones, 2008; Rodríguez, 2010; Barrio and Rodriguez, 2016). When formed in the French paradigm of the $19^{\text {th }}$ century, winemakers and agronomists who arrived at the Southern Cone adopted a negative matrix on the enological quality of Malbec. In addition, as much in Chile as in Argentina, these experts transmitted these concepts through their work and communication. 
The opposite effect occurred with CabernetSauvignon. The recognition of this strain was then in full swing within French viticulture. Most of the specialists recommended their oenological qualities. The universities repeated these ideas, and the brand-new agronomists and winemakers brought it fresh to the Southern Cone of America.

The scale of values of the French paradigm, which was applied in the Southern Cone of America at the end of the $19^{\text {th }}$ century, was reflected in the speech of prepared technicians and agronomists. These criteria were reflected in the works of Damian Hudson (1867), Eusebio Blanco (1870) and Leopoldo Suárez (1911) in Argentina, and Manuel Rojas in Chile (1891). The first acknowledged Quinta Agronómica in Mendoza was the initial pole for the cultivation of French grapes in Argentina. The text states: "The one that excels among them, in terms of the extension of their plantations and its excellent quality, is Bordeaux in two of its species, mainly Cabernet and Gourdaux. Mr. Pouget ten years ago, made some bottles of Bordeaux wine, and every year has increased the number to many dozens. Some other winegrowers already have large plantations of this kind of grape (15 and 20,000 plants each) that does not lower its number of twelve to fifteen people, practicing the cultivation by the method that is used in that Department of France" (Hudson, 1867).

The first ampelographic study published in Buenos Aires gave an account of the birth of the French paradigm in Argentinian territory. The innovative role of the Quinta Agronómica in Mendoza as an experimental station was highlighted; at the Quinta Agronómica, the European plants adapted to the climates and Cuyan soils and soon spread to the private vineyards of the region. In this first observation, we detected the presence of Cabernet-Sauvignon but not of Malbec. The same thing happened with the second author. For Eugenio Blanco, the center of interest of the promising Argentinean viticulture should center around the Cabernet-Sauvignon variety: "The celebrated wine of Bordeaux owes its name to the Cabernets; Cabernet Franco and Cabernet-Sauvignon. The taste of these plants of superior choice gives these famous wines their particular flavor and prints that seal of exquisite refinement that has such a general acceptance" (Blanco, 1870).

These words reaffirmed the concepts introduced by Damian Hudson in the sense of recognizing Cabernet-Sauvignon as the grape with the main enological value of the region. These criteria were shared on the other side of Alps. Manuel Rojas's (1891) Handbook on Vitiviniculture and Wine making (1891) clearly expressed these ideas. When dealing with the stocks recommended for the elaboration of specific wines, the technician indicated that the red Bordeaux wine was structured in a hierarchy of three levels. To obtain first-class wines, only Cabernet-Sauvignon and Cabernet Franco were to be used. For second-class wines, $50 \%$ of the grapes were required to be CabernetSauvignon or Cabernet Franco and 25\% Merlot or Petit Verdot and 25\% Malbec. Finally, for third-class wines, $25 \%$ of the grapes used were Cabernet-Sauvignon and 75\% were Malbec (Rojas, 1891). Later, the same author gave some clarifications about these varieties. Cabernet-Sauvignon was placed within the category of "finer stocks", characterized as yielding grapes of "quality and [a] certain amount". In a lower category, "stocks that follow", the author included Malbec, which was characterized as offering "certain quality and a large amount” (Rojas, 1891). The winemaking paradigm that settled in the Southern Cone in the last third of the $19^{\text {th }}$ century was, in terms of technical-professional speech, clearly inclined towards Cabernet-Sauvignon.

This vineyard was defined as "the most appreciated of the Medoc varieties. Easy to ripen, less fertile, but precocious stock" (Rojas, 1891). On the other hand, Malbec was defined as "a more productive variety than the old Côt, a less colored and inferior wine. Clusters that are more extended, more regular, less sweet, and less pleasant to eat" (Rojas, 1891). 
Rojas's Argentinean counterpart, Leopoldo Suárez, soon shared the ideas of the Chilean winemaker. For Suárez, the Director of the oenological station of the National School of Viticulture in Mendoza and an engineer trained in Conegliano, Cabernet was widely superior to Malbec in terms of enological quality. The clearest and strongest proof of this superiority was its prominence in select French wines. "It is widespread throughout the Bordeaux region, especially in Medoc; it forms part of the elaboration of all the great red, French red 'crus' wines of Pauillac, Saint Julien, etc.; it enters by five octave parts in the plantations of the Chateaux Lafite, Latour, Léoville, Margaux and others. But where it is especially cultivated is in the Graves (Bordeaux)" (Suárez, 1911). By forming the heart of the viticulture considered then the most successful in the world, Cabernet was the most recommended variety for obtaining quality wines in Argentina. With this variety, "wine is the most delicate of those elaborated in the country, a little harsh and tannic when new and rich in extract. It ages slowly, but at the 3 rd or $4^{\text {th }}$ year it acquires a lot of bouquet" (Suárez, 1911).

If the first period of French viticulture in the Southern Cone (the second third of the $19^{\text {th }}$ century) had given an equal outcome for CabernetSauvignon and Malbec, in the next cycle, the situation seemed to favor Cabernet-Sauvignon. This was established by professional technical speech in both countries. In both Argentina and Chile, agronomists simultaneously pondered the enological quality of Cabernet-Sauvignon, relegating Malbec to a lower rank. However, this was only in the eyes of the technocrats.

\section{The peasants' rebellion}

The recommendations of the technical-professional speech had uneven adoption on both sides of the Andes Mountains range. In general terms, Chilean wineries were aligned behind the proposals of the winemakers of Montpellier, while Argentinean winemakers, acting in open rebellion, were as a whole oriented towards Malbec. In the crucial years for modern viticulture in both countries, between the end of the $19^{\text {th }}$ and the beginning of the $20^{\text {th }}$ century, the most lasting divergence of viticulture in the Southern Cone of America occurred, and the winemaking frontier was defined in the Andes Mountains.

In Chile, the spread of French varieties was led by the varieties of the Cabernet group, mainly CabernetSauvignon. Other varieties were also cultivated, such as Pinot, Gamay, Meunier, Semillon Millet, Folle Blanche, Chasselas and, of course, Malbec (Del Pozo, 2014). However, the most relevant variety was the emblematic strain of Bordeaux, CabernetSauvignon, based on the information recorded at the time. Cabernet-Sauvignon was the main strain of red wines in the haciendas of Santiago, Nuñoa, San Bernardo, Limache, Quillota, Victoria, Maipo, Lontué, Talca, and Itata, among others. The sum of these two varieties' acreage exclusively exhibited a proportion of $88 \%$ Cabernet-Sauvignon to $11 \%$ Malbec (Briones, 1995).

In Argentina, the bourgeoisie also fell into line with the recommendations of the technicians. A good example was Elías Villanueva, a conspicuous member of the traditional Cuyan elite class who was several times a governor and a national senator. On his farm in Maipú, Don Elías planted a vineyard of 40 acres of Cabernet, among others. Other entrepreneurs also committed to this variety, with good results: "Cabernet is the plant that so far has produced the finest wine in Mendoza. It is making its way in the many squares of the Republic, with the name of Reserva de Mendoza" (Suárez, 1911). Based on the alliance between the regional bourgeoisie and the technical recommendations, it was predicted that the future of Argentinean viticulture would be led by Cabernet, the same as in Chile: "We are confident that, for a long time, Cabernet will be the best of Mendoza's red wines" (Suárez, 1911).

Despite the recommendations and predictions of the technicians, Argentinean viticulture did 
not take the planned course. Instead, there was a spectacular turn towards Malbec, which became the emblematic national strain. This change occurred between the end of the $19^{\text {th }}$ century and the beginning of the $20^{\text {th }}$ century during the consolidation stage of modern and large-scale viticulture in the region.

As has been noted, in 1912, the Official Records of the Province of Mendoza reflected 57.764 hectares, including 50.207 of French grapes (87\%) and 7.557 of Creole grapes (12\%). According to Galanti, Malbec accounted for $95 \%$ of the French grapes, and, according to the National Wine Center (CVN, 1911), Malbec represented $75 \%$ of the national viticulture. As noted, Suárez attributed Malbec with $80 \%$ of the national viticulture (Suárez, 1911). In any case, the consensus of the specialists pointed out that Malbec was, by far, the most popular variety in Argentina.

The wine-growing divergence between Argentina and Chile was paradoxical, considering the existing isomorphism, both in terms of the time at which the varieties were introduced in both countries and in the discourse's consistency between agronomists and winemakers, exhorted to prioritize Cabernet-Sauvignon as having a higher quality than Malbec. The different development in both countries evidently had another cause.

The different valuations of Malbec and CabernetSauvignon were adapted differentially in Chile and Argentina according to the economic capacities of the emerging wine industry. To understand this divergence, it is appropriate to cite medieval adage "The nobleman eats when he wants, the monk when it is his turn and the poor when he can" (Contreras and Gracia, 2005) to point out that the noble winegrower chooses the variety he wants and the poor the one he can.

The central actor in the process of the modernization of the Chilean wine industry under the French paradigm was the national bourgeoisie. Enriched by other economic activities, especially mining, in the last third of the $19^{\text {th }}$ century, the business class oriented its interests within the world of vine and wine. This twist was possible because of the availability of strong capital. This opulence was felt in all aspects of the new settlements, both in the vineyards and in the industrial installations.

The chateaux flourished, representing the image projected by the French nobles and their vineyards in Chile. The national bourgeoisie were the decisive actors in the eruption of the French paradigm in Chilean viticulture. The role of poor peasants and small winegrowers was minor. The scarcity of land in Chile and the hegemony of the traditional ruling class, reinforced by the victory of the Pacific War and the businesses generated from the acquired income, generated a significant body of capital that, little by little, moved into viticulture. The specialized literature has clearly pointed this occurrence out (Gilbert, 2014).

Indeed, the referents of classic Chilean viticulture came from the most dynamic segments of other economic activities. Melchor Concha y Toro amassed his fortune in mining, as did families such as the Cousiños, Urmenetas and Errázuriz Valdiviesos. Pedro Correa was made wealthy by railways and banks, as Silvestre Ochagavía was by the newspaper La Unión, among other similar cases (Del Pozo, 2014).

The purpose of these members of the bourgeoisie when investing wine-making properties was to add a symbol of social prestige to their economic success. A witness of the time reflected this tendency with the following eloquent words: "Many people object to large expenditures for the construction of warehouses, and show as an example what some large producers of Santiago have invested in this kind of building; 20, 30 and even 40,000 pesos. These wineries are very beautiful, it is true; they are built with all the rules of art, but they are not indispensable. Why do these large expenses, when an adobe warehouse, closed and well guaranteed by wide corridors, lead to the same end? Do you think that the great vintners of France, who are 
usually small, poorly-off owners, make so many expenses? It would not be possible for them. However, their products enjoy a reputation and give them a fortune" (Chapiron, 1869).

The testimony of the French immigrant, who was astonished to see the flourishing of the Chilean chateaux in the attempt to imitate the external aspects of the Old World winemaking, was a sign of the times. The newly rich found in the world of vine and wine a socially accepted means of joining the country's prominent social strata. The attitude of the Chilean economic bourgeoisie, in the sense of turning their capital towards the wine industry as a source of social prestige, contrasted with the situation in Argentina. In the latter country, the national bourgeoisie, enriched by the agricultural exports of the pampas, did not have this impulse. Cuyo viticulture emerged from a local drive encouraged by small vine growers who, little by little, grew along with the wine boom generated by the fulminating rise of the market of Buenos Aires and the connecting railway with Mendoza, established in 1885 .

The migratory barrage that Argentina received when capturing over six million people between the late $19^{\text {th }}$ and early 20 th centuries was the first catalyst of the Cuyano wine boom. In a few years, an enormous market arose where once there had been only a small village. Thus, this activity generated an extraordinary opportunity that was skillfully stimulated by the political class in Mendoza, led by Emilio Civit. Through laws, decrees and other stimulating measures, the generation of the 1880 s generated the conditions for the rapid expansion of the crops in Cuyo. The cultivated area in Mendoza grew from 2,000 hectares in 1880 to 9,000 in 1890, 24,000 in 1905, and 60,000 in 1914. The national bourgeoisie did not participate in this expansion. The key social actors were the creole peasants $(70 \%)$ and immigrants $(30 \%)$. As in Chile, Argentina's viticulture had found new riches. However, these arose not from the transfer of capital from mining to the vineyard but from the vineyard itself. Some immigrants, particularly those adept at business, managed to quickly connect with markets, driving trade flows in their favor and controlling the industrial segment of the activity with the construction of large wine factories. Monstrous settlements arose, including Tomba, Giol-Gargantini, and Arizu, with a capacity ranging between 100,000 and 230,000 hectoliters, which was ten times larger than the existing ones in France. These newly rich people had a dominant position in the wine market. However, their influence on viticulture was lower. They had a few acres of vineyard. Grapes were bought from wine growers. The 60,000 acres that were planted in Mendoza in twenty years were the work of 40,000 small wine growers, who were the key players in the Argentinean wine boom. They financed their vineyards through the results of their own work, that is to say, with the sale of grapes. After the harvest, these winegrowers chose to postpone consumption and reinvest their profits in new vineyards. The concept was described in a report by La Prensa (1914): “The winemaker, everything he has gained in previous years, he has used it to expand the vineyard." The Argentinean vineyards "are purely a local creation, formed by a freehand work force and constant perseverance. Mendoza has made over twenty years what other people have only achieved in centuries." This phenomenon was also noted by the Director of the School of viticulture: "This variety [Malbec] has found very good conditions for its development and adapted perfectly to the climate, terrain, etc. The success achieved by the winemakers with their cultivation caused it spread rapidly in Mendoza and San Juan, to such an extent that today, $80 \%$ of the vineyards belong to this variety" (Suárez, 1911).

The peasants from Cuyo, in their effort to increase their crops, planted Malbec, chasing the dream of economic prosperity. For them, Malbec was the vehicle for decreasing social inequality and improving health and the quality of life. This dream led them to disregard the recommendations 
of the technicians and advance in their persistent alliance with Malbec. In this way, the heart of the Argentinean winemaking heritage was set up.

The hegemony of Malbec in Argentinean viticulture represented the rebellion of the winegrowers against the technocrats. The peasants, in their vineyards, prioritized what they observed in the plants. They chose Malbec, time and time again, to strengthen and extend their vineyards. Stressed by the dilemma of listening to technicians or following their own intuition, the winegrowers were inclined towards the second and affirmed Malbec as an emblematic variety in Argentina.

The peasants in the rebellion in favor of Malbec were silent. None of them came to the public debate to refute the winemakers of Montpellier. Winegrowers lacked the theoretical tools to confront technicians with "scientific" arguments. They were limited to battling on the ground between their strains and ridges. Only in some cases, as required by the press or publications of dissemination, did wine growers and winemakers dare to highlight, with pride, their choice of Malbec. This attitude was never assumed by the large wineries, such as Tomba, Arizu, and Giol-Gargantini, which exceeded 100,000 hl of annual sales. However, the attitude was professed by small and medium-sized wineries, such as Angel Chini, which proudly proclaimed that it produced "between 10,000 and 14,000 hectoliters of the wine type French, Malbec" (Album, 1910).

The vine growers' persistence in the cultivation of Malbec contributed to the establishment of this variety as being emblematic of Argentina. The national market was modeled on the taste for Malbec, to the horror and contempt of the technocrats. "What was the result of this persistence in maintaining an almost unique variety in our wine-growing field? That at the present time, no matter how much the elaboration of the wines is careful and subject to the most progressive technical procedures, it is only possible to elaborate a single kind of common wine, of ordinary type, almost uniform. (...) The type of our wines is essentially national, both because of its technical characters and by the absolute uniformity of class" (Galanti, 1914).

\section{Technocrats and the renewed critics of Malbec}

As Malbec was consolidated as a preferred grapevine for Argentinean winemakers, the technicians and agronomists of the French paradigm increased their criticism. In the 1910s, there was real competition between specialists to despise the quality of Malbec. The National Wine Center (1911); the head of the oenological station, Leopoldo Suárez (1911); the head of the agronomic station, Luis Noussan (1916); and a technician, Arminio Galantí (1914) agreed on this approach. In specialized publications at that time, the above authorities engaged in a dialogue with each other, building a technocratic discourse to demonize Malbec.

The ampelography of Leopoldo Suárez was a central reference in the debate. Using his position as an expert in grape growing, the director of the School of Enology of Mendoza, and a graduate of the famous School of Conegliano, Suárez elaborated the first complete ampelography of Argentina. He dedicated a chapter to the Malbec variety (15-40), in which he gave his global vision, from the French paradigm, of the strengths and weaknesses of this plant, with particular reference to its application in Mendoza. According to Suárez, Malbec was only a useful variety "for an industrial plantation and [for] the production of a cheap wine of good quality".

However, he also noted that "it is not suitable for the production of bottle wines because it persistently retains a typical taste of the earth, which makes it unpleasant and does not reach special qualities with aging". In addition, "by being poor in acidity and tannin, it makes correction necessary which increases the elaboration expenses" (Suárez, 1911). 
Leopoldo Suárez's prestigious position facilitated his approach being taken as representation of the technical-professional opinion of agronomists and winemakers. This became a reference point for advertisers, publishers and specialized journalists. A substantial study from the National Wine Center was supported by the above document, building the study's arguments: "In Cuyo, Malbec predominates. Of the total plantations, Malbec occupies $75 \%$. In the opinion of renowned winemakers such as Leopoldo Suárez, this is a transcendental error due to the deficiencies of the musts that are made with this grape, which claim corrections that import millions of pesos each year" (CVN, 1911).

The technicians expressed themselves from the theoretical perspective of the French paradigm and its $19^{\text {th }}$ century criteria. For them, Cabernet-Sauvignon was necessarily the queen of all varieties, while Malbec was of inferior quality. These criteria were also expressed by Galanti: "Malbec, under the influence of its recognized and well-tested production capacity annihilates all the initiatives that some technicians or less routine winemakers have tried in favour of other varieties of excellent properties. Therefore, neither the cultivation of the Cabernet variety, the Pinot, Verdot, Merlot, Semillon, Sauvignon Rabosa, Barbera, nor others already experienced with success have prospered (Galanti, 1914). One after the other, the technicians and professionals reinforced the anti-Malbec discourse.

Noussan also joined the campaign of criticism towards the economic strains of Malbec and Listán Prieto. Given the supposedly poor wine value of these varieties, Noussan, a graduate of Montpellier, recommended gradually replacing those vineyards with others of higher quality: "The Malbec and Creole varieties can be, with a lot of advantage, replaced by new and better quality wines and have a profitable production such as Barbera, Boyarda de Gattinara, and Fresia for the production of red wines of immediate consump- tion; Pinot Burgundy, Raboso and Tannat for red wines to be consumed after a certain time; Gubelo and Trebiano for the production of white wines for immediate consumption; Cinsaut, Cabernet, Syrah, for fine red wines: Aleático, Bastardo, Grenache, and Riesling for slow aging, very fine white wines" (Noussant, 1916).

According to this technocrat, the wine growers should start economic strains, both the best of the hispanocreoles (Listán Prieto) and the best of the French (Malbec). The cultural value of these cultivars, including their meaningful identity for Argentinean viticulture, was worthless according to Noussan's criterion. From their perspective, it was advisable to change these varieties. As an indicator of Noussan's contemptuous attitude, the star variety of the first three centuries of Southern Cone viticulture was merely called "Creole". Aligned with the French paradigm of the $19^{\text {th }}$ century, which he had learned in the University of Montpelier, Noussan, the head of the agronomic station of Mendoza, recommended other varieties, mainly Cabernet-Sauvignon, for wines of higher quality: "The following mixtures have proved to be very good: wine Creole and Folle Blanche, for white wines, slow, very fine aging; Carignan and Grenache, type Corbiere and Freisa-Raboso for wines of immediate consumption; Folle Blanche and Raboso or Cinsaut, Cabernet, and Folle Blanche for red wines of slow, very fine aging" (Noussant, 1916).

Later, in an article published in the Journal of Agriculture, Industry and Trade (1920), the winemaker insisted on those concepts. He again reduced Listán Prieto to simply being "Creole" and pointed out that both that variety and Malbec had to be used in place of cultivars that had enological quality: "Both varieties currently cultivated on a greater scale are Malbec and Creole, can be used with much advantage, replaced by others of greater merits and, if in truth its fast elimination is not feasible, both technically and economically, it is possible to associate to them, in increasing importance, fruits of other varieties that are 
spread progressively to improve thus the quality of wines" (Noussan, 1920).

From his position of power and prestige, stemming from his position of director of the agronomic station, and arguing from the basis of winemaking experiences carried out in the National School of Viticulture, Noussan, also a winemaker in Montpelier, spread his recommendation to "gradually replace Malbec and Creole grapes". In an article published in Commerce and Industry (1920), "varieties presented by Noussan which can be propagated in Mendoza" were unveiled for the replacement of the previous varieties. Among them, Cabernet-Sauvignon was particularly mentioned (Noussan 1920).

The criticisms from the technocrats, in the sense of minimizing the enological value of the Malbec variety, continued throughout the 1920s. Specialized publications functioned as speakers of the technical approach and insisted on their criticisms to Malbec. In its 1929 volume, the Wine Center Bulletin insisted on the following concepts: "Malbec has spread among us in an enormous proportion, a vineyard of great performance and also serious defects"(287: 480-510). In a century, the core technicians, agronomists and winemakers never varied their position. Stuck in the French paradigm, particularly in their approaches in the $19^{\text {th }}$ century, they kept the traditional scale of values of official enology alive. For this group, the most prized strain was Cabernet-Sauvignon, while Malbec was relegated to the lower strata.

\section{The triumph of the peasants: Malbec as the emblematic Argentinean variety}

The repeated attacks of technocrats against Malbec crashed against peasant resistance in Argentina. Despite the repeated recommendations of winemakers, agronomists and technicians, the small vine growers persisted in defending their favorite variety. The Argentinean vineyards maintained the hegemony of Malbec for a century.
This was verified by the first official Registries of the National Institute of Viticulture. Since its creation by a law in 1959, the institute dedicated itself to constructing annual statistical reports of national vineyards, discriminating by variety. In 1962, 58,577 acres of Malbec were detected, versus 1,310 acres of Cabernet-Sauvignon. The grapevine of Cahors, despite the demonization of the technocrats, rose, victorious, as an emblematic Argentinean variety, greatly surpassing its aristocratic rival, the Cabernet-Sauvignon.

Malbec did not escape the wine crisis that the Argentinean industry underwent two decades later. The variety experienced a strong setback, like the entire Argentinean grape growing industry, which fell from 350,000 to 200,000 acres. However, in the middle of the 1990s, when the trend was reversed, Malbec surged again, mainly in external markets. At the beginning of the exportation of Argentinean wine, the industry detected that spontaneously, the market demanded particularly Malbec. The recurrent ordering of this Argentinean variety disoriented the technocrats and made the winemakers smile. The surface of Malbec quickly recovered and raised from 9,700 acres in 1995 to 22,400 in 2005 and 40,500 in 2016.

The industry recognized this variety as an emblematic stock and projected the corporate image of Argentinean viticulture around it. In parallel, starting in 2007, the success of the Argentinean Malbec wine in the worldwide market caused an extraordinary phenomenon.

For the first time in the history of viticulture, a French Appellation of Origin changed its marketing strategy by prioritizing the variety (Malbec) instead the terroir (Cahors) (Lacoste, 2015; Molina, 2018). At the same time, Chile also underwent a reassessment of Malbec. This variety almost disappearing in Chile in the 1990s; but after the argentine Malbec commercial success, Chilean viticulturist rise over 2,500 acres and growing. Within the Chilean context, CabernetSauvignon is still the hegemonic variety. This 
occurred during the fall of the other cultivars in the 1980s until reaching as low as 11,100 acres in 1994. However, it began recovering, reaching 26,100 acres in 1999, 40,000 in 2004 and 43,200 in 2015, though within Argentina, this vineyard holds its traditional subordinate position in relation to Malbec. The most recent records indicate a surface of 15,000 acres of Cabernet-Sauvignon.

The main conclusions are as follows. The identification with Cabernet-Sauvignon in Chile and Malbec in Argentina established a clear wine border in the Southern Cone of America. This was not a momentary event but a secular trend that began in the $19^{\text {th }}$ century, and is still fully extant in the $21^{\text {st }}$ century. This process occurred within the framework of the implementation of the French paradigm in both countries, marked by the incorporation of both strains in parallel form (Briones, 1995; 2005; Mateu and Stein, 2008; Barrio, 2010a and 2010b; Rodríguez Vázquez, 2010; Del Pozo, 2014). The physical presence of both varieties in the two countries was reinforced by the recommendations of technicians, winemakers and agronomists who believed in the supremacy of Cabernet-Sauvignon over Malbec. This line of thinking agreed with the main references of the time, both in Chile (Rojas, 1891) and in Argentina (Hudson, 1867; Blanco, 1870; Suárez, 1911; Galanti, 1914; Noussan, 1916).

The differential factor spurring the divergence in wine-growing developments between the two countries was the winegrowers. In Chile, the modernization of wine was led by the national bourgeoisie, who were enriched by mining, finance and other economic activities; in Argentina, this role fell to the poor peasants, mainly creoles (two-thirds) and European immigrants (one-third). The Chilean entrepreneurs' greater availability of capital allowed them to comply with the technical recommendations and prioritize the Cabernet-Sauvignon variety. On the other hand, the Cuyo farmers, with fewer resources, chose the most productive strain: Malbec. There were two different attitudes among winegrowers in relation to the technocrats: submission in Chile and rebellion in Argentina. The Argentinean and Chilean wine tastes were modeled accordingly based on these two different attitudes.

The parallelism with gastronomy is evident. In the anthropology of food, "the cuisine of a country is its landscape in the casserole" (Contreras and Gracia, 2005). In the world of wine, it is exactly the same: the Argentinean preference for Malbec reflects the social extraction and vital decisions of the Cuyo peasants in their vineyards. The Chilean tradition of preference for Cabernet-Sauvignon is based on the rotation of the national bourgeoisie, who, in the last third of the $19^{\text {th }}$ century, decided to transfer the resources accumulated through mining, transportation, finance and other activities to raise the vine and wine project in the country.

The differential between grape growers in both countries also had other causes and consequences. Among such causes, it is also necessary to include the greater availability of land in Argentina than in Chile and the change of the social structure generated by the massive number of immigrants arriving there, which contributed to the questioning of the strong social hierarchies that had been reinforced by the old colonial regime. This allowed farmers to assume a leading role in the transformation of Argentinean viticulture, though not in Chile, where the change was mainly directed by the bourgeoisie. The differences in the role of the grape growers in the founding stage of modern grape growing in both countries shaped, to a great extent, the identity of the culture of the wine to this day.

This is reflected in the different ways of representing wine in both countries, including the grape harvest celebrations and the forms of wine culture. In Argentina, free activities such as "classical music in the wine roads" can be accessed by all, as can visits to emblematic sites such as the Museum of the Rural, the National Wine Museum and a grape harvest (in the former Giol-Gargantini palaces). 
In Chile, however, visits to wineries are not free, and their prices are quite high; the aim of the industry is to receive the high and medium high sectors in their warehouses ( $\mathrm{ABC} 1$ and $\mathrm{C} 2)$ - they have little interest in receiving the lower-middleclass and less-popular people (segments $\mathrm{C} 3$ and D). A similar phenomenon is seen at the grape harvest celebrations.

In Argentina, the National Grape Harvest Festival, with its multiple locations throughout the province of Mendoza, mobilizes a million people every year through the participation of those in the artistic proposal sectors, such as Bolivian community, with its parades, and the gay community, with its own parallel party. This popular profile contrasts with the aristocratic grape harvest celebrations in Chile, particularly the one presented by Miguel Torres in Curicó and the one by Carlos Cardoen in Santa Cruz. It seems that the Chilean wine industry is afraid of everyday people, contrary to the situation in Argentina. From a commercial point of view, this asymmetry is also noticeable in the difference in the annual wine consumption per capita, where Argentina exceeds Chile by practically double. In Argentina, the industry has been interested in promoting and strengthening the domestic market, making it possible for the government to recognize wine as a national drink and obtaining a tax exemption for the consumption of wine and sparkling wines. However, in Chile, the industry has not been interested in the domestic market; in Chile, the wine has a specific tax of $20.5 \%$. Because the state taxes the product so heavily, the industry has not built a strong bond with domestic consumers. In some ways, this current asymmetric reality in the culture of wine in Chile and Argentina is consistent with the differentiated process that was generated in the founding period of modern viticulture in both countries and with the sociocultural sense that the wine has had on both sides of the Andes Mountains range since then.

\section{Acknowledgments}

The authors would like to acknowledge the Direction of Research of Universidad Mayor and and Dirección de Ciencia y Tecnología (DICYT) de la Vicerrectoría de Investigación, Desarrollo a Innovación (VRIDEI) de la Universidad de Santiago de Chile (USACH), Proyect "Patrimonio Agroalimentario en Chile Central". DICYTUSACH- 031894LG PS 618 VRIDEI.

\section{Resumen}

P. Lacoste, y P. Pszczolkowski. 2019. Fronteras enológicas en el Cono Sur de América: Cabernet-Sauvignon en Chile y Malbec en Argentina. Cien. Inv. Agr. 46(3): 220-233. El artículo examina las causas de la frontera enológica del Cono Sur de América, situada en la cordillera de los Andes, con el predominio de Malbec al este (Argentina) y Cabernet-Sauvignon al oeste (Chile). Se descubre que esta frontera enológica se estableció en el siglo XIX, cuando en Chile la Cabernet-Sauvignon superaba al Malbec en proporción de nueve a uno, mientras que, en Argentina la Malbec representaba el 75\% de la viticultura nacional. La causa de esta divergencia se encuentra en el distinto sujeto viticultor que protagonizó el proceso de expansión y consolidación del paradigma francés en cada país. En Chile, este papel cupo a la burguesía nacional que orientó hacia la viticultura los capitales acumulados en minería, finanzas y otras actividades; por este motivo pudo acatar el mandato técnico que predicaba la superioridad enológica de la Cabernet-Sauvignon. En cambio, en Argentina, el artífice de la expansión fue el 
campesino pobre, devenido en pequeño viticultor. La escasez de capital lo impulsó a buscar una variedad más productiva y su convicción personal lo llevó a persistir en el cultivo de la Malbec. La rebelión de los pequeños viticultores contra el mandato de los tecnócratas sentó las bases del surgimiento de la Malbec como cepa emblemática de Argentina.

Palabras clave: Cabernet-Sauvignon, cepaje emblemático, Malbec, paradigma francés, viticultura del nuevo mundo.

\section{References}

Aliquo, G., R. Torres, T. Lacombe, J.M. Boursiquot, V. Laucou, J. Gualpa, M. Fanzone, S. Sari, J. Pérez Peña, and J.A. Prieto. 2017. Identity and parentage of some South American grapevine cultivars present in Argentina. Australian Journal of Grape and Wine Research 23(3):452-460.

Barrio, P. (2010a). Crisis y transformaciones en la vitivinicultura mendocina 1890-1955. Mendoza, FFyL, 203 p.

Barrio, P. (2010b). Hacer vino. Empresarios vitivinícolas y Estado en Mendoza (1900-1912). Rosario, Ediciones Prohistoria, 298 p.

Barrio, P., and F. Rodríguez. (2016). Instituciones, saberes y expertos para un Estado provincial: Leopoldo Suárez, de agrónomo a funcionario itinerante del lencinismo, Mendoza, 1918-1930. Boletín del Instituto de Historia Argentina y Americana Dr. Emilio Ravignani, (44):78-107.

Blanco, E. 1870. Manual del viñatero en Mendoza. Extractado y anotado sobre el texto de la $4^{\text {ta }}$ edición francesa del Tratado de Vinificación de Henry Machard. Buenos Aires, Imprenta Americana, $52 \mathrm{p}$.

Briones, F. 1995. Vitivinicultura chilena. Tesis de Magister. Santiago, Universidad de Santiago, 227 p.

Briones, F. 2008. Misiones de estudio y vitivinicultura chilena 1875-1900. Tiempo y espacio 20:61-78.

Centro Vitivinícola Nacional (CVN). 1911. La vitivinicultura argentina en 1910. Buenos Aires, Editores Emilio Coll e hijo.

Chapiron, A. 1869. Cultivo de la viña. Boletín de la Sociedad de Agricultura 1:60-61.
Contreras, J., and M. Gracia. 2005. Alimentación y cultura: perspectivas antropológicas. Barcelona, Ariel, 459 p.

Del Pozo, J. 2014. Historia del vino chileno. Santiago, Editorial LOM, 310 p.

Lucero, J.D. 1991. Andrés Tejeda y Miguel Amado Pouget. Mendoza, Ediciones Culturales, 65 p.

Figeac, M. 2016. In the Age of Enlightenment, when the wine from Cahors flew out to Bordeaux. RIVAR 3(7):11-24.

Galanti, A. 1914. Estudio crítico sobre la cuestión vitivinícola. Publicado originalmente en diario La Nación (Buenos Aires). Reproducido completo en: Barrio (2010a):149-180.

Griset, P., and L. Laborie. 2016. Historiographie et réinvention du vignoble de Cahors, XXe-XXIe siécles. RIVAR 3(7):81-102.

Hudson, D. 1867. La viticultura en Cuyo. Anales de la Sociedad Rural Argentina 15:477-490.

Lacoste, P. 2015. El Malbec de Francia: la Denominación de Origen Controlada "Cahors". Historia y perspectivas. Idesia 33(1):113-124.

Lacoste, P. 2019. La vid y el vino en el Cono Sur de América. Santiago, RIL, 303 p.

La Prensa. 1914. El problema vitivinícola. Investigación realizada por el diario La Prensa (Buenos Aires). Reproducido completo en: Barrio (2010a):125-148.

Marambio, A. 1908. Algo sobre la superficie de las viñas chilenas y su producción. Centro Vitivinícola Nacional 34(4):846-849.

Mateu, A.M., and S. Stein. 2008. El vino y sus revoluciones. Una antología histórica sobre el desarrollo de la industria vitivinícola argentina. Mendoza, EDIUNC, 381 p.

Molina, M. 2018. Appellations of Origin Protected Simultaneously under a Regime of Intellectual 
Property and Intangible Cultural Heritage: Analysis in Argentine Law. RIVAR 5(15):135-156.

Nérand, F.X. 2016. Du Cahors au kagor. Pistes pour une histoire du vin de Cahors en Russie. RIVAR 3(7):25-39.

Noussan, L. 1916. Estudio vitícola enológico de carácter técnico y económico. Publicado originalmente entre 1916 y 1920. Reeditado completo en: Barrio (2010a):195-203.

Pszczólkowski, Ph. 2016. La Côt o Malbec en Chile y Argentina. RIVAR 3(7):58-80.

Pszczólkowski, Ph., J.M. Boursiquot, M. Roques, V. Laucou, and T. Lacombe. 2018. Verdot (Grosse Mérille). An Old and Rare French Vari- ety, Heritage of the Chilean Viticulture. RIVAR 5(14):149-161.

Rodríguez Vázquez, F. 2010. La contribución técnica de Luis Noussan en un período crítico de la vitivinicultura mendocina (1915-1920). En: Barrio (2010a):91-102.

Rojas, M. 1891. Tratado de viticultura y vinificación. Talca, Imprenta La Libertad, 1891, 482 p.

Suárez, L. 1911. Contribución a los estudios ampelográficos en la provincia de Mendoza. Mendoza, Imprenta y Librería González y Cía.

Williot, J.P. 2016. Three paths to integrate the Cahors wine in the history of food. RIVAR 3(7):40-57. 